\title{
Spatial and temporal scales of variation in bacterioplankton community structure in the NW Mediterranean Sea
}

\author{
Jean-François Ghiglione*, Marièle Larcher, Philippe Lebaron
}

\begin{abstract}
Observatoire Océanographique de Banyuls, Laboratoire Arago, Université Pierre et Marie Curie (Paris 6), Institut National des Sciences de l'Univers (INSU) CNRS-UMR-7621, BP 44, 66651 Banyuls-sur-mer Cedex, France
\end{abstract}

\begin{abstract}
An important query in marine microbial ecology is at what temporal and spatial scales variations in the structure of natural bacterial communities occur. Samples of different volumes were collected at different spatial (vertical and horizontal) and temporal (from hours to seasons) scales along a transect between a coastal station (26 m depth) and an offshore Microbial Observatory (1000 m depth) in the NW Mediterranean Sea. The structure of the bacterial communities was determined by capillary electrophoresis-single strand conformation polymorphism (CE-SSCP) fingerprinting of polymerase chain reaction (PCR)-amplified $16 \mathrm{~S}$ rDNA. This technique is a powerful tool to compare natural microbial assemblages at different spatial or temporal scales. Similar bacterial assemblages were found up to $3.7 \mathrm{~km}$ from the coastal station, whereas significant changes were found over greater distances (from 9.3 to $33.3 \mathrm{~km}$ ). Although the bacterial community structure did not change with depth at coastal and shallow stations, vertical changes were found at deeper stations, most likely due to vertical variations in physico-chemical and biogeochemical parameters. Temporal changes were mainly related to environmental variations that occurred at a seasonal scale and during phytoplankton blooms. Finally, we suggest that long-term studies, at least in the NW Mediterranean Sea, should involve a minimum sampling time scale of $2 \mathrm{wk}$ and a shorter time-scale when environmental changes are detected by the real-time monitoring of a few basic parameters (i.e. fluorescence, temperature, salinity). Sampling strategies should also include different depths depending on the vertical structure of the water column, based on the same basic parameters.
\end{abstract}

KEY WORDS: Bacteria $\cdot \mathrm{CE}-\mathrm{SSCP} \cdot \mathrm{Community} \mathrm{structure} \cdot$ Sampling strategy $\cdot$ Microbial observatory

\section{INTRODUCTION}

Micro-organisms represent the most abundant, biogeochemically important organisms in the oceans. At

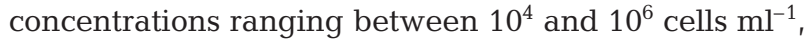
an estimated 20 to $50 \%$ of marine primary productivity is channelled through bacterioplankton (Azam et al. 1983, Cho \& Azam 1990). However, the identity, physiology and ecology of the vast majority of these microbes, as well as the processes they mediate in the environment, remain unknown or poorly understood. Recent advances in molecular biology, genomics, proteomics, bioinformatics, and cultivation technologies herald a new age of exploration of the microbial world.
A network of 'Microbial Observatories' has been developed in different habitats and across environmental gradients in order to explore bacterial diversity and understand the role of bacterial community structure in the functioning of ecosystems. Although several microbial observatories are already operational in North America (www.nsf.gov/bio/pubs/awards/mo03. $\mathrm{htm}$ ), there is an urgent need to define appropriate sampling strategies and analytical tools that should be used for the long-term monitoring of bacterial diversity.

Dynamics of marine pelagic bacterial communities along horizontal transects suggest different trends. Minor differences in community structure have been 
found in surface waters at stations located a few kilometers apart near Anvers Island, Antarctica (Murray et al. 1998), or even between heterotrophic communities separated by $1500 \mathrm{~km}$ in the Arabian Sea (Riemann et al. 1999). In contrast, differences have been found between a coastal and an offshore station, $95 \mathrm{~km}$ apart, off the Catalan Coast, Spain (Schauer et al. 2000), and also among samples from a transect crossing a salinity gradient in the North Sea (Riemann \& Middelboe 2002) or along an estuarine gradient from the Rhone River to the Mediterranean Sea (Troussellier et al. 2002). Variability with depth has been shown to be more marked in marine ecosystems, where changes in community structure are driven by the vertical stratification of waters (Lee \& Fuhrman 1991, Murray et al. 1996, 1998, Acinas et al. 1997, Moeseneder et al. 2001). Marine bacterial communities are also influenced by temporal changes that occur at different time scales, from years or seasons (Lee \& Furhman 1991, Murray et al. 1998, Riemann et al. 1999, Schauer et al. 2000, 2003) to weeks or days (Acinas et al. 1997, Fandino et al. 1998, 2001). These different trends are generally related to variations in physical, chemical and/or biological parameters.

The volume of sample may also be an important factor for drawing up a general description of the genetic community structure. Although a few studies have suggested that sample size has little importance for the community structure as determined by fingerprinting methods (Kirchman et al. 2001, Long \& Azam 2001, Casamayor et al. 2002), this question remains poorly evaluated.

Fingerprinting approaches offer an interesting compromise for the monitoring and comparison of microbial assemblages and for the assessment of temporal and spatial changes that would not have been feasible using time-intensive 16S rDNA sequence analysis. Denaturing gradient gel electrophoresis (DGGE) has become a very popular fingerprinting technique in marine microbial ecology, especially because bands with particular melting behaviour can be excised from the gel and subsequently sequenced to reveal the phylogenetic affiliation of the community members (Muyzer et al. 1998). However, the calibration of the linear gradient of DNA denaturants makes gel-to-gel comparison difficult. This problem has made the DGGE technique impractical for the fine comparison of large number of samples (Moeseneder et al. 1999). The recently developed capillary electrophoresis-single strand conformation polymorphism (CE-SSCP) fingerprinting technique permits high reproducibility for reliable comparison of patterns from a theoretically infinite number of samples (Lee et al. 1996). Because an internal size standard with a different fluorescent label is added to each sample, CE-SSCP and further computing correction solves the problem of gel-to-gel comparison (Zumstein et al. 2000).

This study was undertaken to investigate the temporal and spatial scales at which changes in bacterial community structure occur at a shallow coastal station and at a deep Microbial Observatory both located in the NW Mediterranean. We also evaluated the reliability of the CE-SSCP technique for the long-term analysis of bacterial community structure in terms of both reproducibility and sensitivity (sample volume).

\section{MATERIALS AND METHODS}

Sampling strategy. Seawater was sampled from the North Western Mediterranean Sea at the SOLA station $\left(42^{\circ} 31^{\prime} \mathrm{N}, 03^{\circ} 11^{\prime} \mathrm{E}\right)$ located in Banyuls-sur-mer bay from March 2002 to March 2003. Sampling was performed with 51 Niskin bottles attached to a SeaBird conductivity-temperature-depth (CTD) profiler deployed from the oceanographic RV 'Nereis II' or the RV 'Tethys'. Seawater was processed in the laboratory within $2 \mathrm{~h}$ of sampling.

Seawater $(500 \mathrm{ml})$ was pre-filtered through $3 \mu \mathrm{m}$ pore size filters (47 mm, Nucleopore) to remove most eukaryotic organisms and to prevent clogging of the final filter. Bacterial cells were concentrated onto $0.22 \mu \mathrm{m}$ pore size filters (47 mm, PC Nucleopore) and stored in $2 \mathrm{ml}$ Eppendorf tubes at $-20^{\circ} \mathrm{C}$ until DNA extraction.

Horizontal variability was tested at 20 randomly selected stations between radii of 3 and $200 \mathrm{~m}$ around the SOLA station. The variability was also analysed over a larger scale along a linear coast-offshore transect from the coastal Stn SOLA to stations located at 3.7, 9.3, 16.7, 27.8 and $33.3 \mathrm{~km}$ from Stn SOLA, named Stns A, B, C, D and MOLA (Microbial Observatory of Laboratoire Arago), respectively (Fig. 1). Vertical variations were investigated by sampling at 3, 5, 10, 15 and $20 \mathrm{~m}$ depths at Stn SOLA (maximum depth of $26 \mathrm{~m}$ ), 3 and $50 \mathrm{~m}$ at Stn A (maximum depth of $70 \mathrm{~m}$ ), 3 and $80 \mathrm{~m}$ at Stn B (maximum depth of $90 \mathrm{~m}$ ), 3, 50 and $80 \mathrm{~m}$ at Stn C (maximum depth of $115 \mathrm{~m}$ ), 3 and $80 \mathrm{~m}$ at Stn D (maximum depth of $500 \mathrm{~m}$ ) and 3, 80, 200 and $800 \mathrm{~m}$ at Stn MOLA (maximum depth of $1000 \mathrm{~m}$ ).

Temporal variations were analysed at different scales (from hours to months) at the SOLA station. Samples were collected monthly from March 2002 to March 2003, weekly from March 2002 to May 2002, daily from 23 to 26 April 2002, and hourly every 6 h from midday 25 April to midday 26 April 2002. All samples were collected in triplicate at 3 and $20 \mathrm{~m}$ depths.

A large range of sample volumes $(1000,500,250$, 100,50 and $10 \mathrm{ml}$ ) was collected on 5 March 2002 to investigate the effect of sample size on the community structure determination. 


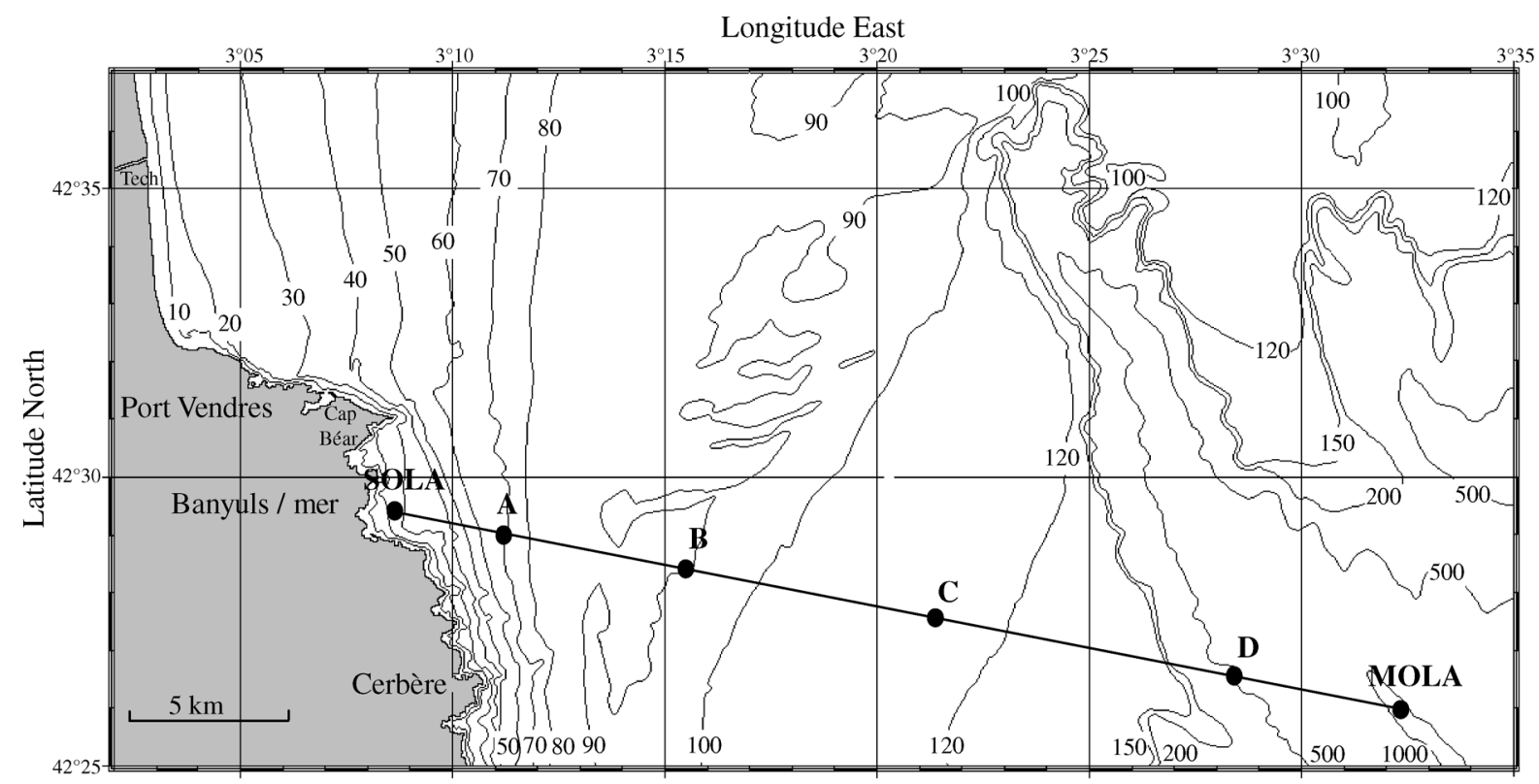

Fig. 1. Location of each sampling station along a linear transect between the coastal Stn SOLA and the offshore microbial observatory (MOLA) in the NW Mediterranean Sea

Bacterial abundances. Total bacterial counts were determined by flow cytometry (Lebaron et al. 1998). Briefly, $2 \mathrm{ml}$ seawater samples were fixed with $2 \%$ formaldehyde for at least $1 \mathrm{~h}$ at $4^{\circ} \mathrm{C}$. A $1 \mathrm{ml}$ sub-sample was incubated with SYBR Green II (final conc. 0.05\% [v/v] of the commercial solution) for at least $15 \mathrm{~min}$ at $20^{\circ} \mathrm{C}$ in the dark and analysed with a FACS Calibur flow cytometer (Becton Dickinson, San Jose, CA) equipped with an air-cooled argon laser (488 nm, $15 \mathrm{~mW}$ ). Stained cells were enumerated according to their side-angle-scattered light (SSC) and green cell fluorescence (FL1) collected through a $530 \pm 30 \mathrm{~nm}$ bandpass filter. Yellow-green fluorescent beads $(1 \mu \mathrm{m}$ diameter, Polysciences) were systematically added to each analysed sample to normalize SSC and FL1 emission. Data acquisition and analysis were done with Cell-Quest software (Becton Dickinson). Acquisition was triggered by FL1. The volume analysed and subsequent estimation of cell concentrations were calculated by measuring the remaining volume and subtracting it from the initial volume. Sheath fluid was seawater filtered through a $0.22 \mu \mathrm{m}$ pore size membrane.

Nucleic acid extraction. The procedure used for extraction of chromosomal DNA was a modification of that described by Fuhrman et al. (1988). This procedure employs an enzymatic and detergent-based lysis, which is a relatively gentle method that avoids excessive shearing of DNA, produces DNA of suitable quality for PCR and reduces the risk of chimera formation during PCR (Madrid et al. 2001).
The frozen $0.22 \mu \mathrm{m}$ pore-size filters were cut with sterilized scissors into small strips and vortexed briefly in $840 \mu \mathrm{l}$ of alkaline lysis buffer (50 mM Tris hydrochloride pH 8.3, 40 mM EDTA, 0.75 M sucrose). Cell lysis was accomplished by an initial incubation for $45 \mathrm{~min}$ at $37^{\circ} \mathrm{C}$ after adding $50 \mu \mathrm{l}$ of freshly prepared lysosyme solution $\left(20 \mathrm{mg} \mathrm{ml}^{-1}\right)$, and a second incubation at $50^{\circ} \mathrm{C}$ for $10 \mathrm{~min}$ after adding $100 \mu \mathrm{l}$ of $10 \%$ sodium dodecyl sulfate and $10 \mu \mathrm{l}$ of proteinase $\mathrm{K}$ $\left(20 \mathrm{mg} \mathrm{ml}^{-1}\right)$. The lysate was extracted with an equal volume of phenol:chloroform:isoamyl alcohol (25:24:1) and with an equal volume of chloroform:isoamyl alcohol (24:1). The nucleic acids were precipitated with 1 volume of isopropanol at $-20^{\circ} \mathrm{C}$ overnight, rinsed with $70 \%$ ethanol before resuspending in TE $(10 \mathrm{mM}$ Tris, $1 \mathrm{mM}$ EDTA). The molecular size and the purity of the DNA were analysed by agarose gel electrophoresis $(1 \%)$ and the DNA was quantified either by visual comparison with the molecular weight markers in gels (rough estimate) or by spectrophotometry (GeneQuant II, Pharmacia Biotech.).

PCR-CE-SSCP of 16S rDNA. The primers used were w49 (5'-ACG GTC CAG ACT CCT ACG GG-3'; Delbès et al. 1998) and w34 (5'-TTA CCG CGG CTG CTG GCA C-3'; Lee et al. 1996), which amplify the variable V3 region of the 16S rDNA (Escherichia coli positions 329-533; Brosius et al. 1981). The primer w34 was fluorescently labelled at the 5 '-end position with phosphoramidite (TET, Applied Biosystems). Both primers were obtained commercially (Eurogentec). Each $50 \mu$ reaction mixture contained $50 \mu \mathrm{M}$ of each 
primer, 1X Pfu reaction buffer, $20 \mathrm{mM}$ dNTPs, $1.0 \mathrm{U}$ of Pfu DNA polymerase (Promega) and $0.1 \mu \mathrm{g}$ of template DNA. PCR amplification was performed with a Robocycler (Stratagene) under the following conditions: an initial denaturation step of $94^{\circ} \mathrm{C}$ for 2 min, followed by 25 cycles of denaturation at $94^{\circ} \mathrm{C}$ for $30 \mathrm{~s}$, annealing at $61^{\circ} \mathrm{C}$ for $30 \mathrm{~s}$, and extension at $72^{\circ} \mathrm{C}$ for $30 \mathrm{~s}$, and a final elongation step at $72^{\circ} \mathrm{C}$ for $10 \mathrm{~min}$. The size (ca $200 \mathrm{bp}$ length) and the amount of PCR products were determined by agarose gel electrophoresis (2\%) with a DNA size standard (Low DNA Mass Ladder, GIBCO BRL).

CE-SSCP procedure. The labelled PCR products were purified with a QIAquick PCR purification kit (Qiagen) according to manufacturer's instructions. Purified PCR products were quantified by visualisation in ethidium-bromide-stained agarose gels (2\%). Samples were diluted (ranging from 1:2 to 1:30) in sterile TE (10 mM Tris, $1 \mathrm{mM}$ EDTA) in order to obtain $10 \mathrm{ng}$ $\mathrm{ul}^{-1}$ of PCR product. From the resulting dilution, $1 \mu \mathrm{l}$ of PCR product was mixed with $18 \mu$ of formamide (Applera) and $1 \mu \mathrm{l}$ of an internal size standard GeneScan-400 Rox (Applied Biosystems). The mixture was then denatured for $5 \mathrm{~min}$ at $94^{\circ} \mathrm{C}$ and immediately cooled on ice for at least $5 \mathrm{~min}$. The procedure used for CE-SSCP analysis was a modification of that described by Delbès et al. (2000). Samples were electrokinetically injected $(5 \mathrm{~s}, 12 \mathrm{kV})$ into a capillary tube $(47 \mathrm{~cm} \times 50 \mu \mathrm{m})$ filled with a $5.6 \%$ GeneScan polymer (Applied Biosystems) gel containing 10\% autoclaved glycerol in sterile TBE buffer $(90 \mathrm{mM}$ Tris-borate, 2 mM EDTA [pH 8.0]). Electrophoresis was carried out at $15 \mathrm{kV}$ and $30^{\circ} \mathrm{C}$ for $30 \mathrm{~min}$ sample $\mathrm{e}^{-1}$ and phosphoramidite (TET)-labelled fragments were detected by a laser with a virtual filter $\mathrm{C}$ (detection wavelengths 532, 537, and $584 \mathrm{~nm}$ ). Data were collected with ABI Prism 310 collection software (Applied Biosystems).

Analysis of CE-SSCP fingerprints. Variations in bacterial community composition were determined from the number and intensity of the peaks. In order to normalize mobilities from different runs, all electropherograms were calibrated by fixing the positions of peaks produced by size standard GeneScan-400 Rox (Applied Biosystems) and by using a second-order least-square curve (i.e. linear regression) to provide the best interlane comparison (Genescan analysis software). Peak detection was achieved by computing the first derivative of a polynomial curve fitted to the data within a window that was centred on each data point (Genescan analysis software). Because many overlapping peaks were present in our profiles, we used a high polynomial degree value of 10 in order to increase peak detection sensitivity. The area of each peak was determined by taking into account the full width of the peak measured at half of its height. The relative area of each peak to the total peak area of each pattern was expressed as a percentage to allow inter-sample comparisons. A peak amplitude threshold of 50 was applied for both the Rox and TET dyes. The UPGMA (unweighted-pair-group method with arithmetic averages) Euclidean distances dendrograms were constructed with the software SYSTAT 5.2.1 from a matrix taking into account the presence or absence of individual peaks and the relative contribution of each peak (in percentage) to the total intensity of each pattern.

\section{RESULTS}

\section{Methodological considerations}

Several tests were performed to investigate the efficiency and reproducibility of the DNA extraction and PCR-CE-SSCP protocols. Cell lysis was monitored several times by microscopy, and in all cases, we did not observe any cells recalcitrant to our lysis procedure. The quality of the DNA (molecular weight and purity) was carefully assessed before proceeding to 16S rDNA gene amplification, and only PCR products showing a single band were used for subsequent analyses. Reproducibility of the PCR-CE-SSCP technique was tested by analysing triplicate samples from the same filtered water that had been collected during 3 successive days at Stn SOLA. Community peak patterns observed between triplicate CE-SSCP analyses were very similar, both in terms of peak number and surface area, suggesting that the different steps from DNA extraction to molecular characterization of the assemblages were very reproducible (Fig. 2).

\section{Effect of sample size}

We sampled a wide range of volumes (from 10 to $1000 \mathrm{ml}$ ) of $3.0 \mu \mathrm{m}$ filtered seawater collected at the SOLA station. All samples were treated identically by filtration through $0.2 \mu \mathrm{m}$ membranes and subsequent DNA extraction. For all samples, total bacterial counts were determined by flow cytometry. A positive correlation was found between bacterial counts and the amount of extracted DNA ( $\mathrm{r}=0.51 ; \mathrm{n}=34 ; \alpha=0.05)$. Before carrying out PCR amplification from the DNA extracts and subsequent CE-SSCP analysis of the PCR products, their concentrations were normalized by diluting to $10 \mu \mathrm{g} \mathrm{ml}^{-1}$ for the DNA extracts and $0.5 \mathrm{ng}$ $\mathrm{\mu l}^{-1}$ for the PCR products (denatured products ready for injection). For samples 50, 100, 250, 500 and $1000 \mathrm{ml}, \mathrm{CE}-\mathrm{SSCP}$ patterns were almost identical with some small differences in peak heights (Fig. 3). For the $10 \mathrm{ml}$ sample, although most major peaks were visible, 


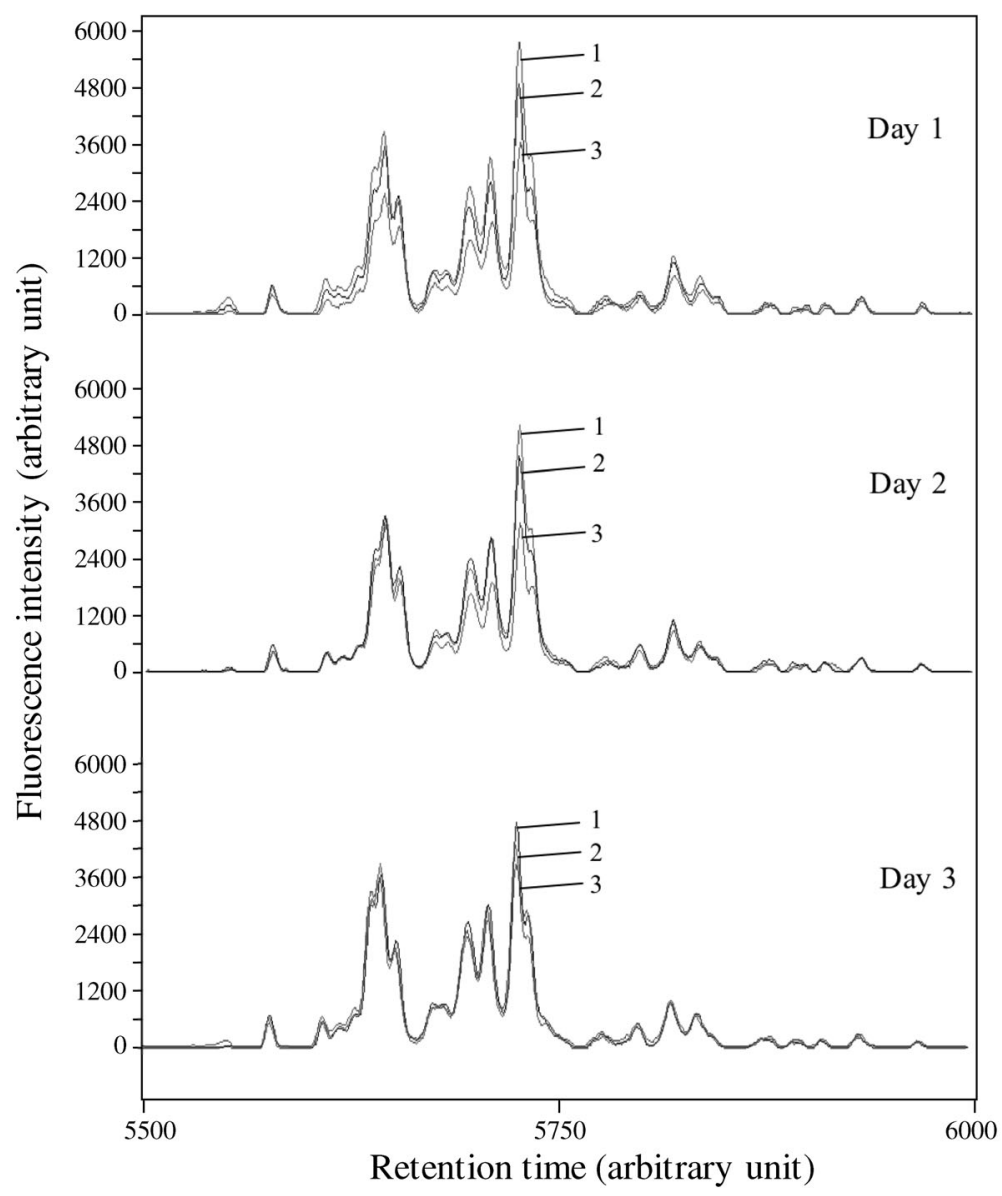

Fig. 2. Reproducibility of CE-SSCP patterns of $16 \mathrm{~S}$ rDNA PCR products of bacterial communities in triplicate samples (labeled 1,2,3) collected on 3 successive days (Days 1, 2 and 3). Retention times are correlated to those for the internal size standard, GeneScan-400 Rox, which were assigned values of 5500 to 6000

some of the smaller peaks were absent, and there were more differences in the heights of the major peaks compared to the other samples (Fig. 3). The richest community peak patterns were obtained for volumes ranging from 50 to $1000 \mathrm{ml}$ of filtered seawater, which corresponded to a minimum of $3 \times 10^{7}$ cells.

\section{Spatial variation scale}

Twenty randomly selected samples were collected within a radius of 3 or $200 \mathrm{~m}$ around Stn SOLA. Bacterial cell counts (from 3.5 to $4.0 \times 10^{5}$ cells ml $^{-1}$ ), as well as the concentration of extracted DNA (from 2.5 to $3.5 \mathrm{\mu g} \mathrm{l}^{-1}$ of filtered seawater), were very similar between samples. CE-SCCP profiles obtained from both radii of 3 and $200 \mathrm{~m}$ around Stn SOLA revealed no obvious spatial differences in the composition of bacterial assemblages, and almost no variation in peak area between samples (data not shown).
Differences in the bacterial composition were observed at a larger spatial scale along the linear coast-offshore transect from the coastal Stn SOLA to stations located 3.7, 9.3, 16.7, 27.8 and $33.3 \mathrm{~km}$ apart, namely Stns A, B, C, D and MOLA, respectively (Fig. 4). When comparing surface samples collected at all stations, 44 peaks were found and among these peaks, 15 were detected at all stations. In contrast, 5 peaks were found at only 1 sampling site; 4 of these peaks were specific to Stn MOLA and 1 to Stn D. When considering peak intensities as determined from peak area, the 4 specific peaks detected at Stn MOLA were significant, each peak representing from 1 to $4 \%$ of the community pattern.

The number of CE-SSCP peaks per sample varied from 25 to 33 and was higher at Stns SOLA, A and D than at Stns B, C and MOLA (Fig. 4a). The community structure at Stns SOLA and A (3.7 km apart) presented the same pattern with only a few differences in the relative intensity of each peak. Differences in microbial community composition were found from $9.3 \mathrm{~km}$ (Stn B) off the Stn SOLA. Fig. 4b shows the corresponding UPGMA Euclidean distances dendrogram which takes into account the presence or absence of individual peaks and the relative contribution of each peak (in percentage) to the total intensity of the pattern (including additional samples collected at different depths). Surface samples (3 m) clustered according to their proximity to one another along the transect from the coastal to the offshore stations. Stns SOLA and A formed a distinct cluster from the nearest one, which was composed of Stns B and C. This result indicates that at least in this sampling area, and along this coast-offshore transect, variations in the structure of surface communities can be observed at stations located at least $9.3 \mathrm{~km}$ from each other. As expected, surface samples collected at Stn MOLA, located $33.3 \mathrm{~km}$ from Stn SOLA, clustered in a distinct branch and therefore were significantly different from samples collected at other stations.

Vertical variations at Stn SOLA were examined in samples taken at 3, 5, 10, 15 and $20 \mathrm{~m}$ depths. Bacterial cell and DNA concentrations remained constant with depth, ranging from 5 to $7 \times 10^{5}$ cells $\mathrm{ml}^{-1}$ and from 4.2 to $4.8 \mathrm{\mu g} \mathrm{l}^{-1}$ of filtered seawater, respectively. Most peaks were found throughout the vertical profile, but one additional peak accounting for $6.6 \%$ of the total intensity was only detected at the deepest depth of $20 \mathrm{~m}$ (data not shown). Variations 


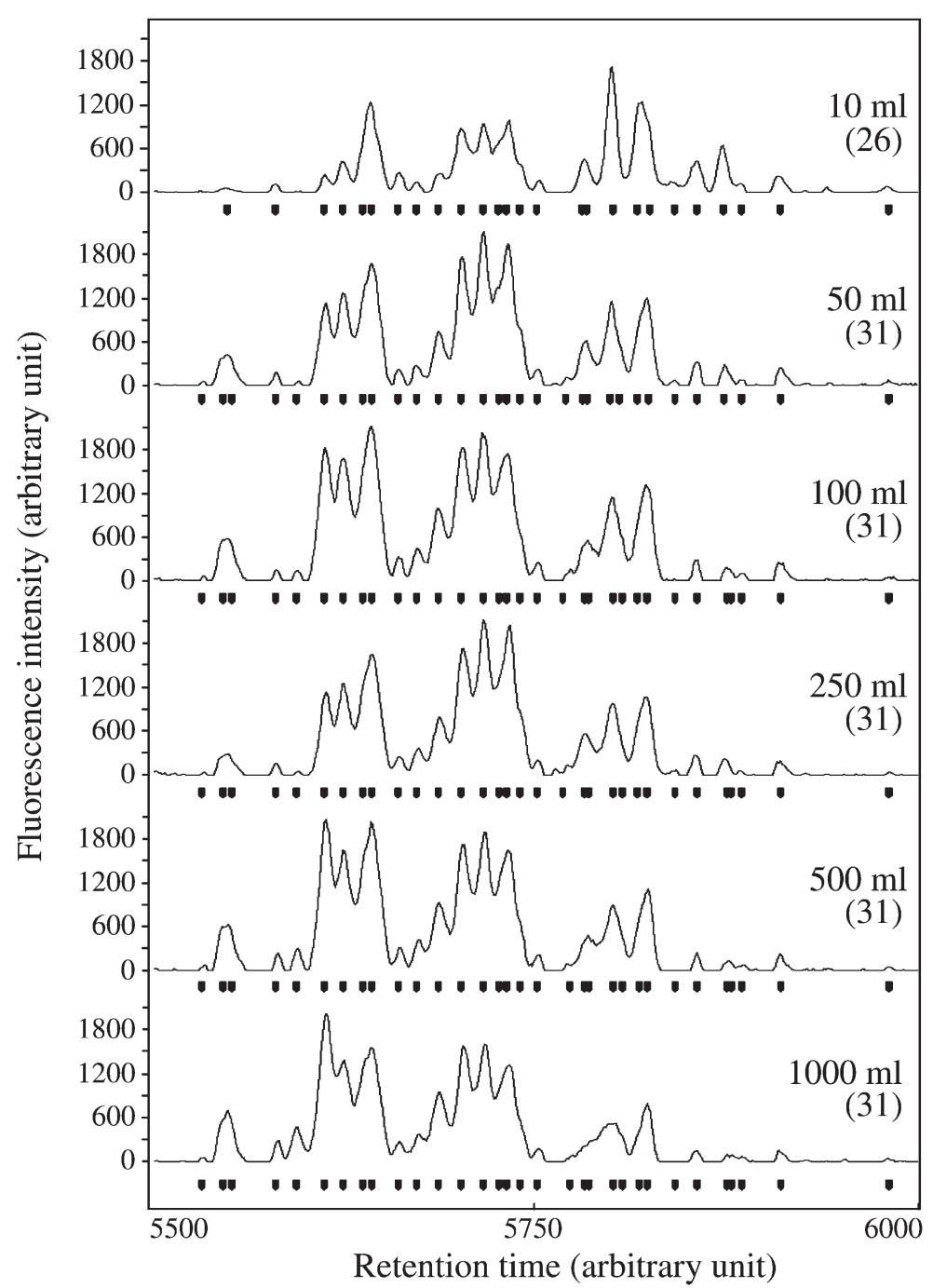

Fig. 3. CE-SSCP patterns of $16 \mathrm{~S}$ rDNA PCR products of bacterial communities from sample volumes varying from 10 to $1000 \mathrm{ml}$ of seawater collected at $3 \mathrm{~m}$ from Stn SOLA. Arrows indicate the peak positions. The total number of estimated peaks per sample are indicated in brackets. Retention times are correlated to those for the internal size standard, GeneScan-400 Rox

with depth were also investigated at other stations (surface and above the bottom for Stns SOLA, A, B, $\mathrm{C}$ and MOLA) and including the deep chlorophyll maximum (DCM) at Stns C, D and MOLA (namely C $-50 \mathrm{~m}, \mathrm{D}-80 \mathrm{~m}$ and $\mathrm{M}-80 \mathrm{~m}$ ). The percentage of common peaks at a given station ranged from 89 to $100 \%$ at Stns SOLA and A, and from 48 to $77 \%$ at deeper Stns B, C and MOLA (data not shown). Clear changes in bacterial community structure were observed between depths at a given station, except for the shallow Stns SOLA and A (Fig. 4b). Samples taken at Stn MOLA clustered together but with relatively low similarity (Fig. 4b).

\section{Temporal variation scale}

Variability in bacterial community structure was investigated at different time scales in surface waters (3 $\mathrm{m}$ depth) at Stn SOLA. Samples collected every $6 \mathrm{~h}$ during $24 \mathrm{~h}$ and daily during 4 consecutive days (from 22 to 25 April 2002) showed some variations in both bacterial cell and DNA concentrations (from 5.4 to $7.0 \times 10^{5}$ cells ml $^{-1}$ and from 3 to $5 \mu \mathrm{g} \mathrm{l}^{-1}$ of filtered seawater, respectively). However, the number and intensity of the peaks were highly constant at both hourly and daily scales (data not shown).

In contrast, changes were observed at larger time scales. Weekly variations were found during a 3 mo survey in spring 2002 (Fig. 5). A phytoplankton bloom occurred during this period with a maximum chl $a$ concentration on 14 May 2002 (see below). Among the 36 peaks found when considering all samples, 26 were persistent as they were present for all sampling dates, and most of these were detected during the course of the bloom. Interestingly, CE-SSCP peak intensities revealed that persistent peaks were not always dominant, since $25 \%$ of these peaks were minor peaks (below $1 \%$ in relative intensity) (Fig. 5a). The entire community structure remained unchanged during 5 consecutive weeks, from 12 March until 10 April 2002. During the 3 mo tested, all peaks were present in at least 2 consecutive weekly samples (Fig. 5a), suggesting that a given pattern was stable during a minimum of $8 \mathrm{~d}$. During the weekly survey, chl a concentration

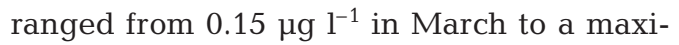
mum of $3.14 \mathrm{\mu g} \mathrm{l}^{-1}$ for only $1 \mathrm{wk}$ in May (sampling date: 14 May 2002). At this time scale, the maximum concentration of chl a was associated with the highest number of bacterial cells $\left(1.2 \times 10^{6}\right.$ cells $\mathrm{ml}^{-1}$ during $2 \mathrm{wk}$ ) and with the highest number of CE-SSCP peaks observed during this period ( 33 peaks; Fig. 5a). Five new peaks accounting for 0.8 to $2.7 \%$ of the total peak area appeared at that time, and they remained for the next $2 \mathrm{wk}$, suggesting that the corresponding bacteria were responding to the organic matter input. Cluster analysis of patterns and the relative intensities of the CE-SSCP peaks are presented in Fig. 5b. Samples fell into 3 major clusters separated by small shifts in bacterial abundance, corresponding to maxima of $8.5 \times 10^{5}$ and $11.2 \times 10^{5} \mathrm{cells} \mathrm{ml}^{-1}$ on 10 April and 14 May 2002 $\left(\right.$ mean $=7.6 \times 10^{5}$ cells ml ${ }^{-1}, \mathrm{SD}=2.6 \times 10^{5}$ cells ml $^{-1}$ for the $11 \mathrm{wk}$ period), respectively. During this period, 


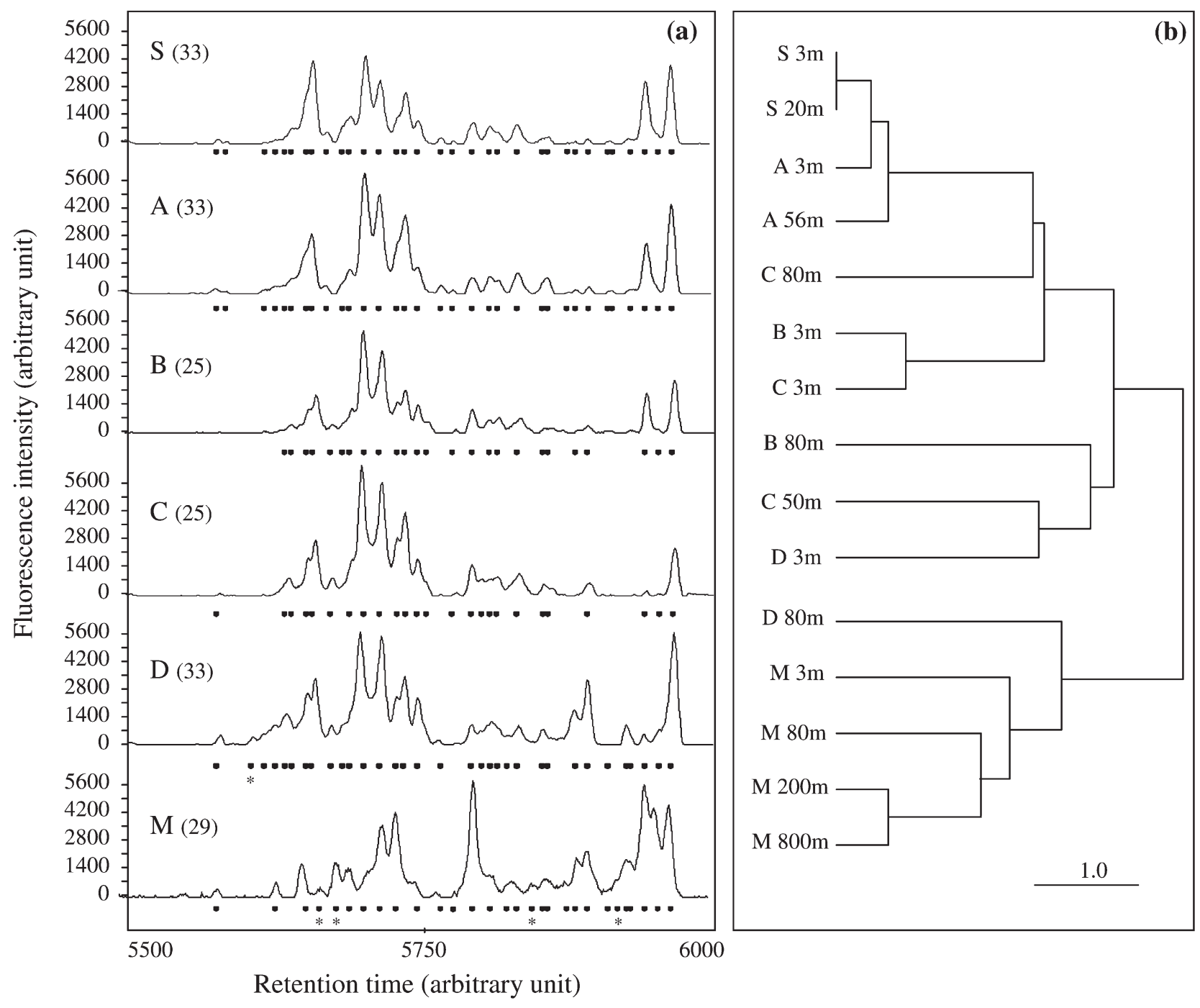

Fig. 4. Community structure of samples from Stns SOLA (S), A, B, C, D and MOLA (M) along a transect from coastal to offshore stations sampled on the same day in July 2003. (a) CE-SSCP patterns of 16S rDNA PCR products of bacterial communities sampled at $3 \mathrm{~m}$. Arrows indicate the peak positions. Retention times are correlated to those for the internal controls. The total number of estimated peaks per sample are indicated in brackets. Peaks detected only at 1 station are marked with an asterisk. (b) UPGMA Euclidean distance dendrogram generated from the CE-SSCP profiles of the transect samples analysed. The different depths are indicated for each station. Scale bar indicates the Euclidean distance

the maximum chl a concentration $\left(3.14 \mu \mathrm{g} \mathrm{chl} \mathrm{a} \mathrm{l}^{-1}\right)$ was

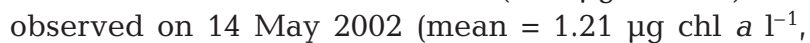

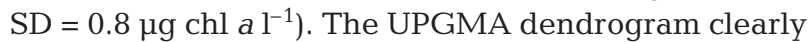
showed that bacterial communities from pre- and post-bloom samples were different (Fig. 5b).

Variability at the monthly scale was investigated during a 13 mo period from March 2002 to March 2003. Fifteen peaks out of a total of 44 peaks identified were found on each sampling date, suggesting that almost one-third of the total number of peaks persisted throughout the year (Fig. 6a). For a given sample, persistent peaks represented between 44 to $60 \%$ of the total number of peaks per profile. The mean number of peaks per sample was $30(\mathrm{SD}=2.9)$, and the highest numbers were found during the spring (May 2002) and winter (January 2003) phytoplankton blooms. No clear relationship was found between the number of peaks and bacterial abundances. As reported at the weekly scale, only a third of the persistent peaks were also dominant peaks (more than $5 \%$ of the relative intensity per sample). During the entire course of the year, bacterial community profiles from different months were always different from each other (Fig. 6a). When subjected to cluster analysis based on Euclidean distance matrix, 3 clusters could be discriminated (Fig. 6b). The UPGMA dendrogram showed that shifts from one cluster to another were strongly related to phytoplankton blooms (March 2002 and January 2003; Fig. 6c). 
(a)

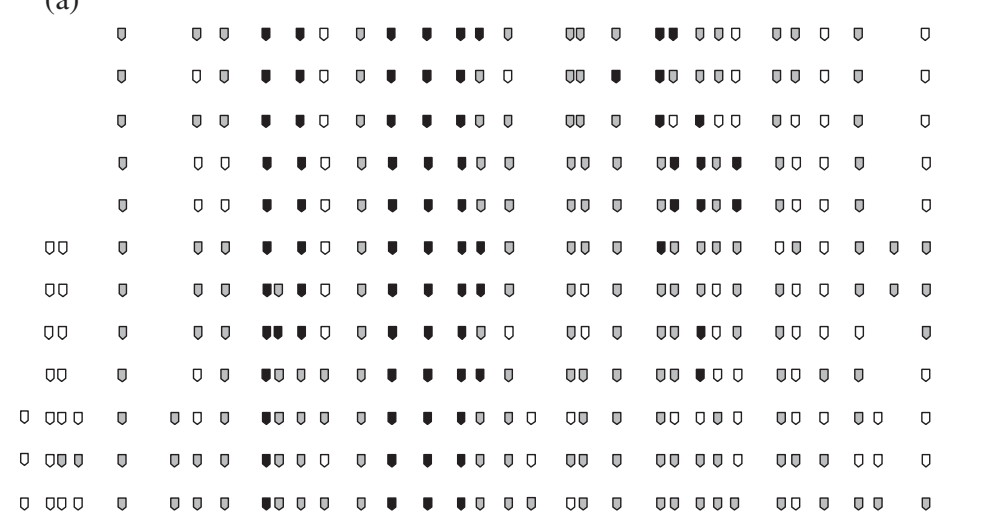


dures (Wintzingerode et al. 1997, Bano et al. 2002, Schauer et al. 2003). Thus, molecular fingerprints may not reflect the exact environmental bacterial diversity and do not allow the consideration of ribotype abundances as absolute values. However, we assume that the relative intensity of detected peaks can be compared between samples because of normalization procedures and the high reproducibility of CE-SSCP. Another limit common to most fingerprinting methods is the potential overlap of different ribotypes and, therefore, the potential underestimation of the diversity of ribotypes. Different bacterial species may have closely related 16S rDNA sequences (Wintzingerode et al. 1997) that could correspond to the same CE-SSCP peak. Similarly, Schauer et al. (2000) mentioned the subjectivity in deciding whether a very weak DGGE band is a real band or a background artefact. In our study, this problem was, at least partly, overcome by taking into account the presence or absence of individual CE-SSCP peaks and the relative contribution of each peak to the total surface area of the pattern. Furthermore, the use of Euclidean distances (UPGMA dendrogram) was very helpful for the final treatment and interpretation of the data. As it was pointed out elsewhere (Riemann et al. 2000, Fandino et al. 2001), we cannot exclude the presence of peaks originating from eukaryotes in the CE-SSCP profiles since the PCR primers used in this study can amplify plastid $16 \mathrm{~S}$ rRNA genes. However, this should not greatly affect our results, since picoeukaryotes never represented more than $1 \%($ mean $=0.4, \mathrm{SD}=0.4)$ of total cell counts in the fraction 0.2 to $3 \mu \mathrm{m}$ (data not shown).

The sample size is of great importance in defining the sampling strategy to provide a representative picture of the bacterial community structure at a given location. The appropriate size may depend on different criteria, including the spatial distribution of bacterial species and the resolution of the methods used to determine the community structure of the dominant species. Our results showed an increasing number of ribotypes per samples up to $50 \mathrm{ml}$, which then remained constant for greater volumes (26 ribotypes for $10 \mathrm{ml}$ and 31 ribotypes for 50 to $1000 \mathrm{ml}$, respectively). Other reports based on the DGGE method suggested that the community structure was not affected by the sample size for volumes ranging from milliliters to liters (Kirchman et al. 2001, Casamayor et al. 2002). Similarly, Long \& Azam (2001) were able to analyse bacterial communities at the microscale level (from microliter to milliliter) to investigate the role of targeted populations in processes that can appear at a microscale level but are invisible at higher scale. In this study, we were not able to obtain representative patterns using very small volumes. A minimum of $3 \times$ $10^{7}$ cells (in our case $50 \mathrm{ml}$ of coastal seawater) were necessary to provide representative $\mathrm{CE}-\mathrm{SSCP}$ patterns (Fig. 3). Differences with other reported studies may be due to the detection sensitivity of each method, but may also be explained by different evenness of the studied communities and/or by a few differences in analytical protocols and reagents. From these results, we determined that further investigations in this area will be undertaken using a minimum of $50 \mathrm{ml}$.

\section{Horizontal variations in bacterial community structure}

Spatial variation in bacterial community structure was also determined at different horizontal scales. Our results showed that bacterial assemblages from surface samples were very similar up to $3.7 \mathrm{~km}$ from $\mathrm{Stn}$ SOLA, at Stn A, and differences appeared from $9.3 \mathrm{~km}$ (Stn B) off Stn SOLA (Fig. 4a,b). Interestingly, the structure of bacterial communities in surface waters changed gradually from coastal to offshore stations. The more striking differences were seen between Stn SOLA and the offshore Microbial Observatory (MOLA), which are $33.3 \mathrm{~km}$ apart (Fig. 4b). These changes along the transect may be explained by the local hydrodynamic regime and an increasing influence of offshore waters along the coast-offshore transect. Four ribotypes were detected only at MOLA and may be of great interest for the long-term monitoring at this station. Analyzing temporal fluctuations may help to better understand the ecological properties of these species. Among the 44 ribotypes found in surface waters along the transect, 15 were always present and probably had enough functional plasticity to adapt to both coastal and offshore marine environments. Unfortunately, the CE-SSCP technique used alone does not allow the identification of species by subsequent sequencing. However, the results can be compared with those of clone libraries of 16S rDNA sequences to provide information on which species are present over seasons or along gradients (Delbès et al. 2000). At stations located in the NW Mediterranean Sea but $94.5 \mathrm{~km}$ south of the Banyuls-sur-mer bay, Schauer et al. (2000) reported large changes in the bacterial community structure between stations located $70.4 \mathrm{~km}$ apart on the Spanish Catalan coast and the open sea. In contrast, almost identical DGGE patterns were obtained from samples taken $1500 \mathrm{~km}$ apart along a transect from coastal waters to the open Arabian Sea (Riemann et al. 1999). These opposite results are likely due to variations in the environmental characteristics of these waters and suggest that further investigations will be necessary to determine which environmental factors regulate these changes.

Almost a third of the ribotypes persisted during the year at Stn SOLA (Fig. 6a). This finding suggests that 
some bacterial populations can, to some extent, adapt to and proliferate in a changing environment. This is particularly true in coastal ecosystems subject to environmental changes such as sediment resuspension events, and river inputs of freshwater and terrestrial material. Interestingly, we observed that these persistent ribotypes are not always dominant in terms of relative abundance, although they may represent key species in the functioning of these ecosystems and probably play a key role in the resilience of the ecosystems. Again, further investigations should be performed to identify these species by combining CE-SSCP with the analysis of clone libraries.

\section{Vertical variations in community structure}

Vertical variations were also analysed at different stations. During the 8 mo monitoring period at Stn SOLA, similar patterns were found for most samples, and the highest recorded differences between the 2 depths ( 3 and $20 \mathrm{~m}$ ) were 2 peaks (data not shown). One explanation of the stability of the profiles could be the lack of stratification at this shallow station (values available at http://www.obs-banyuls.fr/Services/sola/). The few differences observed could be due to some sediment resuspending events, which often occur in this very windy part of the Mediterranean coast. UPGMA analysis also showed that surface and deep waters at Stn A (70 m depth) located $3.7 \mathrm{~km}$ from Stn SOLA were only slightly different (Fig. 4b), possibly for the same reasons cited above for Stn SOLA. In contrast, differences were found at deeper stations (B, C, D, MOLA) that could be related to a progressive stratification of the water column along the coastoffshore transect, with a clear deep chlorophyll maximum (DCM) found from Stn C to offshore. The different depth samples collected at MOLA clustered together according to their proximity to one another in the water column (Fig. 4b). The offshore Microbial Observatory was chosen because of its special location on top of the Lacaze-Duthiers Canyon, which is responsible for the episodic cascading of dense water that affects the hydrology of the area and plays an important role in the transfer of matter (Bethoux et al. 2002). Similar vertical stratification of the bacterial community structure has commonly been found in a wide diversity of oligotrophic seawaters, including the Pacific and Atlantic Oceans, the Caribbean Sea (Lee \& Fuhrman 1991), the Mediterranean Sea (Acinas et al. 1997, Moeseneder et al. 2001) and Antarctic zones (Murray et al. 1998). Therefore, any long-term monitoring should combine different sampling depths according to the physico-chemical and biological properties of the water column. Further investigations are needed to better understand why some species are always present along the vertical profiles and why others are not.

\section{Temporal variations in bacterial community structure}

Temporal variations in bacterial community structure were found at Stn SOLA at the largest temporal scales (weeks to seasons) but not at a shorter time scale (hours or days). These changes occurred at a minimum time scale of $2 \mathrm{wk}$ (Fig. 5a). It suggests that bacterial populations in this oligotrophic area did not change very fast in response to environmental changes, since a given assemblage was constant for up to 5 successive weeks. During the year, the most important changes in bacterial community structure were strongly related to the occurrence of phytoplankton blooms (Fig. 6). These events provide rapid and more or less (depending on the bloom) important inputs of organic matter that result in a dynamic response of the bacterial community. This was characterized at Stn SOLA by increases in both cell counts (from 5 to $15 \times 10^{5}$ cells ml ${ }^{-1}$ ) and bacterial production (from 0.1 to $0.35 \times 10^{-6} \mathrm{~g} \mathrm{C}^{-1} \mathrm{~h}^{-1}$ ). During the spring and winter blooms (Fig. 6c), the maximum concentrations of chlorophyll $a$ were associated with the highest number of CE-SSCP peaks observed during the year, with the appearance of new ribotypes that were maintained for at least $2 \mathrm{wk}$ (Figs. 5a \& 6a). The UPGMA dendrogram confirmed that bacterial communities from pre- and post-bloom samples were different (Figs. 5b \& 6b). Other reports demonstrated that bacterial community successions are commonly associated with the formation and senescence of phytoplankton blooms, likely reflecting the proliferation of bacterial ribotypes specialized in particle colonization and degradation (Van Hannen et al. 1999, Riemann et al. 2000, Fandino et al. 2001, Riemann \& Winding 2001, Schäfer et al. 2001). For example, greater species richness was observed in microcosms enriched with diatom detritus (Long \& Azam 2001).

We are not aware of other investigations on temporal variations in bacterial community structure from hourly to seasonal scales in marine ecosystems. Because of cruise logistics and meteorological considerations, temporal variations in bacterioplankton assemblages are usually observed at larger time scales, comparing samples collected from year to year (Lee \& Fuhrman 1991, Riemann et al. 1999), in different seasons (Murray et al. 1998, Schauer et al. 2000) or daily in a few cases (Acinas et al. 1997, Fandino et al. 1998). By comparing DGGE profiles of 18 different samples taken during 1998, Schauer et al. (2003) showed bacterial 
community changes at time scales ranging from weeks to months at a site very close to our sampling area (Blanes Bay, Spain). They suggested that changes in dissolved organic matter supply mediated by different algal populations might be one of the main factors affecting bacterioplankton composition. These results and those presented here suggest that temporal variations should be monitored at different time scales, depending on the questions to be answered. Sampling every month should be probably more than enough for the long-term monitoring of bacterial communities in a given area if the aim is to determine the effect of environmental changes occurring at a large scale (i.e. climate change). In contrast, weekly samplings should be carried out to observe the effects of environmental changes which occur at short time scales (i.e. phytoplankton blooms, freshwater input in coastal areas, local pollution, etc.) if the aim is to further understand the functional role of bacterial biodiversity in the cycling of nutrients.

The long-term monitoring of oceanic regions at Microbial Observatories is of special interest for discovering and characterizing novel micro-organisms, microbial consortia, activities and other novel properties, and to understand the role of microbial community structure in the functioning of ecosystems over time and across environmental gradients. This work underlined the fact that a reliable method should be used, which allows the analysis of a large data set. The CE-SSCP method seems to be a good candidate for this purpose. Then, observations require the use of appropriate temporal and spatial scales, which depends on the question to be answered. At deep stations, variations in bacterial community structure were generally greater on vertical than on regional scales due to higher vertical than regional variation in biotic (primary production, grazer community) and abiotic (nutrients, temperature, pressure) variables. For the same reasons, temporal variations are mainly controlled by changes in biotic and abiotic factors and the most important variations seems to be driven by phytoplankton blooms in the NW Mediterranean Sea.

Acknowledgements. We thank the captains and the crews of the RV 'Tethys' and the RV 'Nereis II' for their help during sampling, especially R. Lafont, N. Rey and J. L. Martinez. We thank the people involved in the long-time series of hydrobiogeochemical data collected within the SOMLIT network and more particularly L. Oriol, L. Zudaire, E. Maria and J. J. Naudin. We thank S. Emonet for his contribution to sampling and DNA extraction and N. Batailler for her contribution to flow cytometry analysis. We are also grateful to N. West for critical reading of the manuscript. Financial support was provided by PNEC grant (2002/1140712) and by the EU program BASICS (EVK3-CT-2002-00018).

\section{LITERATURE CITED}

Acinas SG, Rodriguez-Valera F, Pedrós-Alió C (1997) Spatial and temporal variation in marine bacterioplankton diversity as shown by RFLP fingerprinting of PCR amplified 16S rDNA. FEMS Microbiol Ecol 24:27-40

Azam F, Fenchel T, Field JG, Gray JS, Meyer-Reil LA, Thingstad F (1983) The ecological role of water-column microbes in the sea. Mar Ecol Prog Ser 10:257-263

Bano N, Hollibaugh JT (2002) Phylogenetic composition of bacterioplankton assemblages from the Arctic Ocean. Appl Environ Microbiol 68:505-518

Bethoux JP, Durieu de Madron X, Nyffeler F, Tailliez D (2002) Deep water in the western Mediterranean: peculiar 1999 and 2000 characteristics, shelf formation hypothesis, variability since 1970 and geochemical inferences. J Mar Syst 33-34:117-131

Brosius J, Dull TJ, Sleeter DD, Noller HF (1981) Gene organization and primary structure of a ribosomal RNA operon from Escherichia coli. J Mol Biol 148:107-127

Casamayor EO, Massana R, Benlloch S, Ovreas L and 6 others (2002) Changes in archaeal, bacterial and eukaryal assemblages along a salinity gradient by comparison of genetic fingerprinting methods in a multipond solar saltern. Environ Microbiol 4:338-348

Cho BC, Azam F (1990) Biogeochemical significance of bacterial biomass in the ocean's euphotic zone. Mar Ecol Prog Ser 63:253-259

Delbès C, Godon JJ, Moletta R (1998) 16S rDNA sequence diversity of a culture-accessible part of anaerobic digestor bacterial community. Anaerobe 4:267-275

Delbès C, Moletta R, Godon JJ (2000) Monitoring of activity dynamics of an anaerobic digester bacterial community using 16S rRNA polymerase chain reaction-single-strand conformation polymorphism analysis. Environ Microbiol 2:506-515

Fandino LB, Riemann L, Steward GF, Long RA, Azam F (1998) Bacterial succession during a dinoflagellate bloom analysed by DGGE and rDNA sequencing. EOS Trans 79(1), OS63

Fandino LB, Riemann L, Steward GF, Long RA, Azam F (2001) Variations in bacterial community structure during a dinoflagellate bloom analyzed by DGGE and 16S rDNA sequencing. Aquat Microb Ecol 23:119-130

Fuhrman JA, Comeau DE, Hangstrom A, Chan AM (1988) Extraction from natural planktonic microorganisms of DNA suitable for molecular biological studies. Appl Environ Microbiol 6:1426-1429

Kirchman DL, Yu L, Fuchs BM, Amann R (2001) Structure of bacterial communities in aquatic systems as revealed by filter PCR. Aquat Microb Ecol 26:13-22

Lebaron P, Parthuisot N, Catala P (1998) Comparison of blue nucleic acid dyes for flow cytometric enumeration of bacteria in aquatic systems. Appl Environ Microbiol 64: 1725-1730

Lee DH, Zo YG, Kim SJ (1996) Non-radioactive method to study genetic profiles of natural bacterial communities by PCR-single-strand-conformation polymorphism. Appl Environ Microbiol 62:3112-3120

Lee SH, Fuhrman JA (1991) Spatial and temporal variation of natural bacterioplankton assemblages studied by total genomic DNA cross-hybridization. Limnol Oceanogr 36: 1277-1287

Long RA, Azam F (2001) Microscale patchiness of bacterioplankton assemblage richness in seawater. Aquat Microb Ecol 26:103-113

Madrid VM, Taylor GT, Scranton MI, Chistoserdov AY (2001) 
Phylogenetic diversity of bacterial and archaeal communities in the anoxic zone of the Cariaco basin. Appl Environ Microbiol 67:1663-1674

Moeseneder MM, Arrieta JM, Muyzer G, Winter C, Herndl GJ (1999) Optimization of terminal-restriction fragment length polymorphism analysis for complex marine bacterioplankton communities and comparison with denaturing gradient gel electrophoresis. Appl Environ Microbiol 65: 3518-3525

Moeseneder MM, Winter C, Herndl GJ (2001) Horizontal and vertical complexity of attached and free-living bacteria of the eastern Mediterranean Sea, determined by 16S rDNA and 16S rRNA fingerprints. Limnol Oceanogr 46:95-107

Murray AE, Hollibaugh JT, Orrego C (1996) Phylogenetic compositions of bacterioplankton from two California estuaries compared by denaturant gradient gel electrophoresis of 16S rDNA fragments. Appl Environ Microbiol 62:2676-2680

Murray AE, Preston CM, Massana R, Taylor LT, Blakis A, Wu K, DeLong EF (1998) Seasonal and spatial variability of bacterial and archaeal assemblages in the coastal waters near Anvers Island, Antarctica. Appl Environ Microbiol 64:2585-2595

Muyzer G, Brinkhoff T, Nübel U, Santegoeds C, Schäfer H, Wawer C (1998) Denaturing gradient gel electrophoresis (DGGE) in microbial ecology. In: Akkermans ADL, van Elsas JD, de Bruijn FJ (eds) Molecular microbial ecology manual, Vol 3.4.4. Kluwer Academic Publishers, Dordrecht, p 1-27

Riemann L, Middelboe M (2002) Stability of bacterial and viral community compositions in Danish coastal waters a depicted by DNA fingerprinting techniques. Aquat Microb Ecol 27:219-232

Riemann L, Winding A (2001) Community dynamics of freeliving and particle-associated bacterial assemblages during a freshwater phytoplankton bloom. Microb Ecol 42: $274-285$

Riemann L, Steward GF, Fandino LB, Campbell L, Landry

Editorial responsibility: Jed Fuhrman,

Los Angeles, California, USA
MR, Azam F (1999) Bacterial community composition during two consecutive NE Monsoon periods in the Arabian Sea studied by denaturing gradient gel electrophoresis (DGGE) of rRNA genes. Deep-Sea Res II 46:1791-1811

Riemann L, Steward GF, Azam F (2000) Dynamics of bacterial community composition and activity during a mesocosm diatom bloom. Appl Environ Microbiol 66:578-587

Schäfer H, Bernard L, Courties C, Lebaron P and 7 others (2001) Microbial community dynamics in Mediterranean nutrient-enriched seawater mesocosms: changes in the genetic diversity of bacterial populations. FEMS Microbiol Ecol 34:243-253

Schauer M, Massana R, Pedrós-Alió C (2000) Spatial differences in bacterioplankton composition along the Catalan coast (NW Mediterranean) assessed by molecular fingerprinting. FEMS Microbiol Ecol 33:51-59

Schauer M, Balagué V, Pedrós-Alió C, Massana R (2003) Seasonal changes in the taxonomic composition of bacterioplankton in a coastal oligotrophic system. Aquat Microb Ecol 31:163-174

Troussellier M, Schäfer H, Batailler N, Bernard L and 5 others (2002) Bacterial activity and genetic richness along an estuarine gradient (Rhone River plums, France). Aquat Microb Ecol 28:13-24

Van Hannen EJ, Zwart G, van Agterveld MP, Gons HJ, Ebert J, Laanbroek HJ (1999) Changes in bacterial and eukaryotic community structure after mass lysis of filamentous cyanobacteria associated with viruses. Appl Environ Microbiol 65:795-801

Wintzingerode FV, Göbel UB, Stackebrandt E (1997) Determination of microbial diversity in environmental samples: pitfalls of PCR-based rRNA analysis. FEMS Microbiol Rev 21:213-229

Zumstein E, Moletta R, Godon JJ (2000) Examination of two years of community dynamics in an anaerobic bioreactor using fluorescence polymerase chain reaction (PCR) single-strand conformation polymorphism analysis. Environ Microbiol 2:69-78

Submitted: November 15, 2004; Accepted: June 30, 2005 Proofs received from author(s): October 13, 2005 